\title{
Eksistensi Ekstrakulikuler dan Konstribusinya dalam Peningkatan Strandart Kompetensi Lulusan di SMAN 2 Lamongan
}

\author{
Moch Faizin Muflich \\ Prodi Pendidikan Agama Islam Universitas Islam Lamongan \\ E-mail: faizin.muflih@gmail.com \\ Rokim \\ Prodi Pendidikan Agama Islam Universitas Islam Lamongan \\ E-mail: rokim060674@gmail.com
}

\begin{abstract}
Abstrak: Berdasarkan Peraturan Menteri Pendidikan Nasional Nomor 62 tentang Kegiatan Ekstrakurikuler Tahun 2014 disebutkan bahwa pengembangan potensi peserta didik yang disebutkan dalam tujuan pendidikan nasional dapat dicapai melalui kegiatan ekstrakurikuler. Kegiatan ekstrakurikuler melibatkan minat siswa di luar bidang formal. Seperti di SMADA Lamongan, ada beberapa kegiatan ekstrakurikuler, antara lain: mengaji, PMR, pencak silat, pengibaran bendera, majalah roman akademik, kelompok kerja kreatif, koperasi, paduan suara, teater, drum band, tari dan informasi teknologi. Ini jelas akan mempengaruhi siswa yang mengikutinya. Kegiatan ekstrakurikuler melibatkan minat siswa di luar bidang formal. Seperti di SMADA Lamongan, ada beberapa kegiatan ekstrakurikuler, antara lain: mengaji, PMR, pencak silat, pengibaran bendera, majalah roman akademik, kelompok kerja kreatif, koperasi, paduan suara, teater, drum band, tari, informasi teknologi, dll. Ini jelas akan mempengaruhi siswa yang mengikuti. Oleh karena itu, perlu diadakan kegiatan ekstrakurikuler untuk meningkatkan kemampuan lulusan yang meliputi tiga aspek yaitu sikap, pengetahuan dan keterampilan. Siswa tidak dapat menerapkan pengetahuan yang mereka peroleh di kelas untuk kehidupan sehari-hari.
\end{abstract}

Kata Kunci : Ekstrakurikuler, Standar Kompetensi Lulusan

Abstract: In accordance with the Regulation of the Minister of National Education Number 62 of 2014 concerning Extracurricular, it states that the development of the potential of students as referred to in the goals of national education can be realized through extracurricular activities. Extracurricular deals with student interests outside of their formal fields. As in SMADA Lamongan, there are several extracurricular activities including; recitation of the Koran, PMR, pencak silat, flag raising troops, scholarly romance magazines, creative working groups, cooperatives, choirs, theater, drum bands, dance, information technology etc. This clearly has an impact on the students who follow. Extracurricular deals with student interests outside of their formal fields. As in SMADA Lamongan, there are several extracurricular activities including; recitation of the Koran, PMR, pencak silat, flag raising troops, scholarly romance magazines, creative working groups, cooperatives, choirs, theater, drum bands, dance, information technology etc. This clearly has an impact on the students who follow. For this reason, extracurricular activities are also needed in improving the competence of graduates which includes three dimensions, namely the 
attitude dimension, the dimension of knowledge and the dimension of skills. Students cannot apply the knowledge they have acquired in class to their daily lives.

Key words: extracurricular, Competency Standards Graduates

\section{Pendahuluan}

Berdasarkan Peraturan Menteri Pendidikan Nasional Nomor 62 tentang Kegiatan Ekstrakurikuler Tahun 2014 disebutkan bahwa pengembangan potensi peserta didik yang disebutkan dalam tujuan pendidikan nasional dapat dicapai melalui kegiatan ekstrakurikuler, dan kegiatan ekstrakurikuler merupakan salah satu kegiatan ekstrakurikuler. Perencanaan kurikulum dan kegiatan ekstrakurikuler dapat mendorong pengembangan potensi siswa melalui pengembangan kreativitas, bakat dan minat, serta kemampuan berkomunikasi dan bekerja sama dengan orang lain. ${ }^{1}$ Kegiatan lain di luar jam sekolah yang bertujuan untuk memperkaya dan memperluas pengetahuan dan kemampuan siswa merupakan kegiatan ekstrakurikuler, kegiatan ekstrakurikuler merupakan wadah tercetak selain pembelajaran formal di sekolah.

Kegiatan ekstrakurikuler melibatkan minat siswa di luar bidang formal. seperti di SMADA Lamongan, ada beberapa kegiatan ekstrakurikuler, antara lain: mengaji, PMR, pencak silat, pengibaran bendera, majalah roman akademik, kelompok kerja kreatif, koperasi, paduan suara, teater, drum band, tari, informasi teknologil. Ini jelas akan mempengaruhi siswa yang mengikuti. Kemudian karena dengan adanya kegiatan ekstrakurikuler sekolah berdampak signifikan terhadap siswa sekolah maka kegiatan ekstrakurikuler akan mempengaruhi hasil cetakan sekolah/ apakah lulusannya memenuhi harapan sekolah, yang tentunya mendukung nilai yang sangat baik atau sebaliknya lulusan.

Untuk mencapai tujuan pendidikan nasional tersebut, perlu dilakukan sertifikasi kemampuan lulusan sesuai dengan ketentuan standar kemampuan lulusan. Dalam tafsir Pasal 35 Undang-Undang Nomor 20 Tahun 2003 tentang Sistem Pendidikan Nasional dikemukakan bahwa standar kompetensi lulusan merupakan batasan kompetensi lulusan yang meliputi sikap, pengetahuan dan keterampilan peserta didik yang harus dituntaskan. atau dicapai oleh siswa. Satuan pendidikan.

Standar kompetensi lulusan merupakan standar yang berkaitan dengan kualifikasi kompetensi lulusan, meliputi sikap, pengetahuan, dan keterampilan. Sasaran standar kompetensi lulusan digunakan sebagai acuan utama pengembangan standar isi, standar proses, standar evaluasi pendidikan, standar pendidik dan pendidik, standar sarana dan prasarana, standar manajemen, dan standar pembiayaan. Standar kompetensi lulusan mencakup standar kompetensi lulusan yang berkualitas yang diharapkan

SMADA Lamongan merupakan sekolah berstandar nasional yang diharapkan dapat melatih lulusan yang berintegritas dan berilmu luas.Oleh karena itu, atas kepedulian tersebut, peneliti akan melakukan kegiatan ekstrakurikuler di SMADA Lamongan untuk mempelajari dan meningkatkan standar kompetensi siswa. lulusan.

Berdasarkan latar belakang pertanyaan atau prinsip dasar diatas, maka penulis dapat menentukan berapa pertanyaan berdasarkan pembahasan berikut, pertanyaan tersebut adalah: Apakah partisipasi siswa dalam kegiatan ekstrakurikuler berpengaruh yang signifikan

\footnotetext{
${ }^{1}$ Permendikbut no 62 tahun 2014 tentang ekstrakurikulers
} 
terhadap kompetensi lulusan di SMADA Lamongan. Penelitian ini menggunakan metode diskrptif kaulitatif, yaitu suatu prosedur penelitian yang dapat menghasilkan data diskriptif berupa ekspresi tertulis atau lisan masyarakat, dan perilaku yang bisa dicermati, ${ }^{2}$ Dalam hal ini penulis hanya menjelaskan keabsahan data yang diperoleh dan melakukan analisis yang cermat terhadap masalah yang diteliti. Penelitian ini menggunakan data kualitatif yang diperoleh dari guru dan kepala sekolah yang didasrkan pada wawancara, observasi, dan dokumentasi. Metode yang digunakan adalah menggunakan alat pedoman observasi dan pedoman wawancara. Untuk melakukan observasi langsung ditempat. Melalui observasi langsung, peneliti akan mendapatkan pemahaman secara umum tentang apan yang terjadi dan apa yang terjadi selama kegiatan keagamaan. Analisis deskriptif megunakan metodologi kualitatif untuk menganalisis data. Artnya analisis data dilakukan dengan mengorganisasikan dan menganalisis secara sestematif semua data yang diperoleh.

\section{Standar Kompetensi Lulusan}

\section{Kompetensi Lulusan}

Kompetensi Adalah kemampuan untuk melakukan tindakan dan berfikir secara bersama-sama dan merupakan perwujudan dari dimensi sikap, dimensi keterampilan, dimensi pengetahuan, yang melekat pada diri siswa, Standar kompetensi Adalah Ukuran minimal yang wajib dipenuhi oleh seorang siswa, sesudah mengikuti proses pembelajaran di satuan pendidikan tertentu, pada saat yang sama, Lulusan memiliki satu makna, yang bermula dari kata dasar lulus. Lulusan mempunyai arti pada kata benda/kelas, sehingga lulusan bisa menyebutkan nama orang, semua benda dan tempat, Lulusan adalah mereka yang lulus ujian. Dari pengertian diatas dapat ditafsirkan bahwa Kompetensi Kelulusan yaitu kemampuan berprestasi, bertindak dan berpikir secara bersama-sama, serta merupakan perwujudan dari keterampilan, pengetahuan, sikap orang yang lulus ujian.

\section{Standar Kompetensi Lulusan}

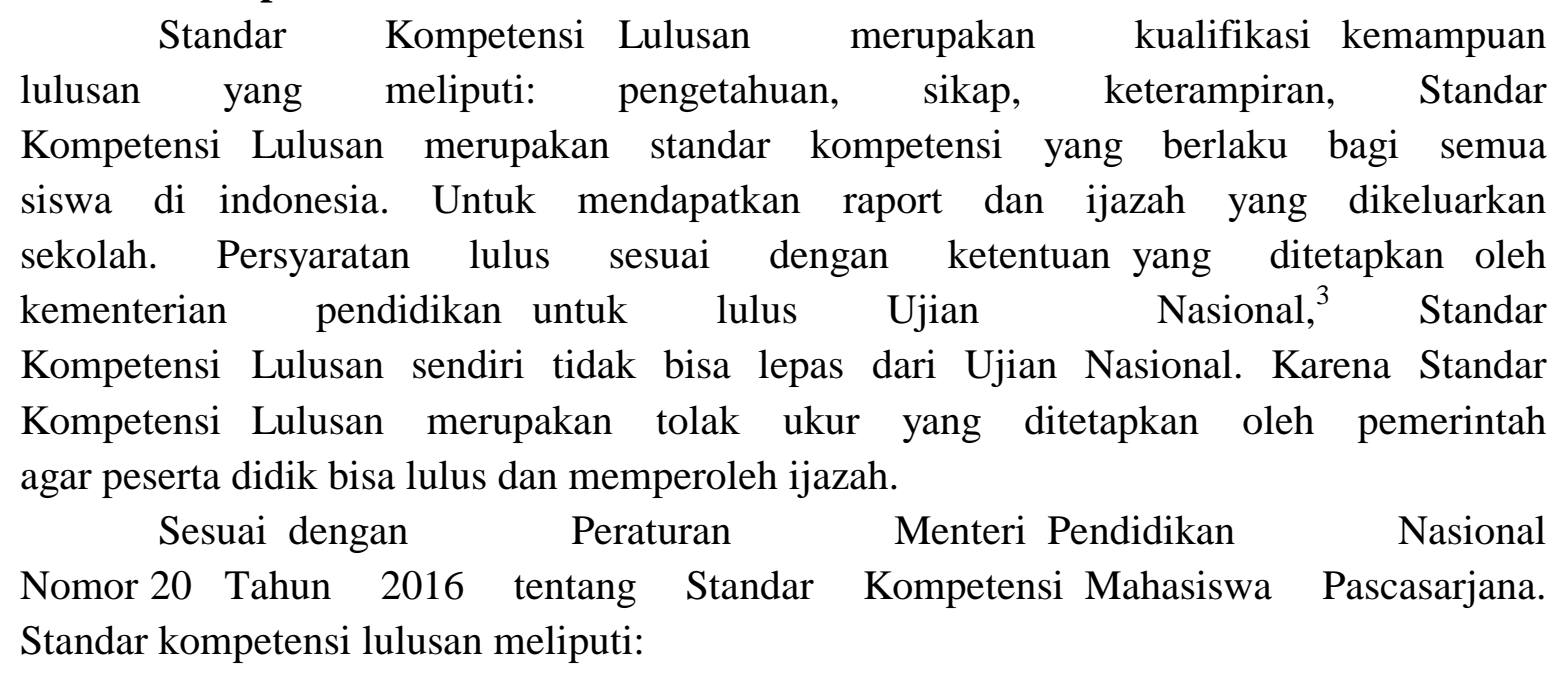

\footnotetext{
${ }^{2}$ Lexy Moeleong., Metodologi Penelitian Kualitatif (Bandung: Remaja Rosdakarya, 1999), 3.

${ }^{3}$ Badan Standar Nasioanal Pendidikan, Peraturan Menteri Pendidikan Nasional tentang ujian Madrasah /Sekolah dan Standar Kompetensi Lulusan (Jakarta: Departemen Pendidikan Nasional, 2006), 2.
} 
a. Siswa memiliki pengetahuan ( dimensi pengetahuan ) tentang fakta, konsep, proses, dan pengetahuan metakognitif, yang meliputi : sains, budaya, hurmaniora, seni, teknologi, serta mampu menggabungkan pengetahuan dengan latarbelakang yang mereka miliki, sekolah, keluarga, lingkungan alam, masyarakat, negara, dan kawasan internasional

b. Siswa memiliki sikap ( dimensi sikap ) perilaku yang mencerminkan sikap siswa. Sesuai dengan pertumbuhan anak dalam keluarga, masyarakat, lingkungan alam, sekolah, kebangsaan, negara, mereka percaya diri, bertakwa kepada Tuhan yang maha Esa, berkarakter, jujur, peduli, tanggung jawab, dan pembelajaran sejati seumur hidup orang, kesehatan fisik dan mental, regional, dan internasional.

c. Siswa memiliki berbagai keterampiran ( dimensi keterampiran ) untuk bertindak dan berpikir : pengembangan melalui metode ilmiah, inovasi, produksi, kritik, kemandirian, kolaborasi, dan komunikasi sebagai pengembangan yang kita pelajari di satuan pendidikan bersumber secara mandiri.

\section{Latar Belakang dan Tujuan Standar Kompetensi Lulusan}

Pasal 31 Ayat 3 Undang-Undang Dasar Negara Republik Indonesia Tahun 1945 Mengatur bahwa Pemerintah menyelenggarakan sistem Pendidikan Nasional, dalam rangka penyelenggaraan kehidupan ilmu pengetahuan yang diatur oleh negara, serta menumbuhkan keimanan, taqwa, dan akhlaq mulia, sesuai dengan hukum, sejalan dengan tugas tersebut, lahirlah Undang- Undang tentang Pendidikan Nasional Tahun 2003 Nomor 20

Menurut Undang-Undang Tentang Pendidikan Nasional Tahun 2003 Nomor 20 Pasal 2, berpijak pada Undang-Undang Dasar Negara Republik Indonesia Tahun 1945 dan Pancasila sekaligus Pasal 3 menegaskan bahwa peran Pendidikan Nasional adalah untuk mengembangkan pembentukan karakter dan kemampuan serta peradaban suatu negara yang bermartabat mencerdaskan kehidupan bernegara, hal ini bermaksud untuk mengembangkan potensi siswa, dan menjadikan dirinya sebagai manusia yang taqwa, beriman, kepada Tuhan yang maha Esa, sehat, berilmu, berakhlaq mulia, mandiri, kreatif, cakap, demokratis serta menjadi warga Negara Indonesia yang bertanggung jawab

Untuk dapat mencapai Pendidikan Nasional tersebut, perlu dilakukan sertifikasi Kemampuan Kelulusan sesuai dengan ketentuan Standar Kemampuan Kelulusan, Dalam tafsir Undang-Undang Tahun 2003 Nomor 20 pasal 35, dijelaskan bahwa Standar Kompetensi Lulusan merupakan batasan Kompetensi Lulusan yang meliputi: Pengetahuan, Sikap, Keterampilan, serta jenjang pendidikan menengah yang harus dicapai atau dicapai oleh departemen pendidikan dasar,

Standar Kompetensi Lulusan dibuat acuan utama dalam penyusunan Standar evaluasi pendidikan, Standar keuangan, Standar menejemen, Standar proses, Standar Isi, Standar pendidik, Standar Sarana dan Prasarana. Standar Kompetensi Lulusan mencangkup kemampuan peserta didik yang diharapkan bisa tercapai sesudah menyelesaiakan Studi pada jenjang Menengah dan pendidikan dasar.

Untuk mengetahui kesesuaian Standar Kompetensi Lulusan harus menggunakan Monitoring dan Evaluasi, hasil dari Monitoring dan evaluasi ini akan dijadikan masukan -masukan untuk meningkatkan Standar Kompetensi Lulusan yang akan datang 


\section{Kegiatan Ekstrakurikuler dalam Meningkatkan Kompetensi Lulusan}

\section{Ekstrakurikuler}

Sesuai dengan ketentuan Menteri Pendidikan Nasional Nomor 22 Tahun 2006 tentang Standar Isi. Satuan pendidikan Menengah dan pendidikan dasar.Dalam kesepakatan tersebut ditetapkan bahwa struktur kurikurum masing-masing satuan pendidikan terdiri dari 3 bagian yaitu :Muatan lokal,Mata pelajaran,dan pengembangan diri, bagian pengembangan diri merupakan kegiatan pelayanan konsultasi dan kegiatan ekstrakurikuler, dalam hal ini kegiatan pengembangan diri meliputi bagian dari kurikurum tingkat pertama bidang pendidikan

Ekstrakurikuler mengacu pada kegiatan yang dilakukan disekolah atau diluar jam sekolah ,Tujuannya untuk memperluas pengetahuan siswa. Menghubungkan mata pelajaran yang relevan,menanamkan bakat dan minat. Serta melengkapi pengetahuan tentang perkembangan manusia secara keseluruhan. Melakukan kegiatan ini secara rutin atau hanya pada waktu-waktu tertentu dan dievaluasi ${ }^{4}$

Wiyani mengartikan Kegiatan Ekstrakurikuler merupakan kegiatan yang dilakukan dalam pengembangan aspek tertentu yang terdapat dalam kurikurum yang sedang berjalan. Termasuk kegiatan yang berkaitan dengan bagaimana siswa sebenarnya menerapkan apa yang telah dipelajari. Sesuai dengan kebutuhan hidup dan kebutuhan belajarnya. Kegiatan ekstrakurikuler di lingkungan sekitar merupakan kegiatan pendidikan yang dilaksakan diwaktu senggang. Yang dapat membantu siswa berkembang melalui kegiatan yang secara khusus diselenggarakan oleh siswa atau pendidik dengan kemampuan dan kewenangan sekolah, kegiatannya dilaksanakan sesuai dengan kebutuhan, potensi, minat dan bakatnya, ${ }^{5}$

Sedangkan Renaning Mendefisikan kegiatan ekstrakurikuler sebagai kegiatan lain di luar struktur yang direncanakan dan biasanya merupakan kegiatan opsional. Sementara itu. Menurut suryabrata kegiatan ekstrakurikuler mencangkup semua kegiatan sekolah yang tidak ditentukan dalam kurikurum, dan beberapa kegiatan ekstrakurikuler dikoordinasikan dan dilaksanakan oleh sekolah. $^{6}$

Kegiatan Ekstrakurikuler merupakan kegiatan yang pada umumnya dilakukan dikelas dan Ekstrakurikuler ( kurikulum ) untuk mengembangkan potensi sumber daya manusia (SDM) siswa. Hal ini tidak hanya terkait dengan penerapan pengetahuan yang diperolehnya, tetapi juga arti khusus untuk membimbing siswa melalui kewajiban dan kegiatan selektif untuk mengembangakan potensi dan bakat batinnya, motivasi siswa mengikuti kegiatan ekstrakurikuler biasanya dikaitkan dengan kesadaran diri. Namun ada juga beberapa alasan, seperti kegiatan kepramukaan dan sekolah lain mengharuskannya untuk digunakan ${ }^{7}$

Kegiatan ekstrakurikuler merupakan kegiatan pembelajaran yang dilaksanakan diluar kelas reguler. Aktivitas masuk sekolah pada pagi hari dilakukan sampai pada sore hari. Dan aktivitas pulang sekolah dilakukan pada sore hari. Kegiatan ekstrakurikuler ini biasanya bertujuan untuk mengembangkat seperangkat mata pelajaran yang diminati siswa. Seperti :

\footnotetext{
${ }^{4}$ M. Saputra Yudha, Pengembangan Kegiatan Ekstrakurikuler (Jakarta: Kemendikbud, 2014), 6.

${ }^{5}$ Andry Novan Wiyani, Menumbuhkan Pendidikan Karakter di SD (Konsep, Praktek, dan Strategi) (Jogjakarta: Ar-ruzz media ,2013, 107.

${ }^{6}$ Suryabrata, Psikolog Pendidikan (Jakarta: PT Rajagrafindo Persada.2011), 58

${ }^{7}$ Yanti Noo, Rabiatul adawiyah, Harpani matnuh, "Pelakasanaan Kegiatan Ekstrakurikuler Dalam Rangkah Pengembangan Nilai-Nilai Karakter Siswa untuk Menjadi Warga Negara yang Baik Di SMA Korpri Banjarmasin "Jurnal Pendidikan Kewarganegaraan : Vol. 6, Nomor 11, Mei (2016), 969.
} 
FPI, olahraga. Seni , karawitan, dan berbagai keterampiran lain seperti kediatan kepramukaan $^{8}$

Kegiatan Ektrakurikuler merupakan kegiatan lain yang dilaksanakan diluar struktur mata pelajaran dan diluar jam sekolah normal. Dengan tujuan untuk memperkaya dan memperluas pengetahuan dan kemampuan siswa. Bentuk kegiatan ekstrakrikuler adalah kegiatan yang dapat menunjang yaitu menunjang perencanaan dikelas melalui hobby bisa menumbuhkan pengetahuan dan kemampuan nalar siswa, keterampiran, serta mengembangkan rencana dikelas dan program sikap yang ada pada masyarakat berupa program intrakurikuler dan program kokurikuler. ${ }^{9}$

Dari beberapa definisi tentang ekstrakurikuler yang sudah dijabarkan diatas. Dapat disimpulkan bahwa kegiatan ekstrakurikuler dilaksanakan diwaktu senggang .untuk meningkatkan pengetahuan siswa serta mengamati bakat dan minat siswa.

\section{Prinsip Kegiatan Ekstrakurikuler}

Dalam Pedoman Pengembangan Diri Menteri Pendidikan Nasional dan Kebudayaan Republik Indonesia Tahun 2006 Nomor 22 Juga menjelaskan prinsip kegiatan kegiatan ekstrakurikuler sebagai berikut :

a. Pemilihan di dasarkan pada keinginan siswa dan prinsip kegiatan Ekstrakurikuler yang siswa ikuti secara sukarela

b. Partisipasi aktif adalah prinsip kegiatan ekstrakurikuler yang menuntun siswa untuk berpatisipasi secara penuh

c. Individual adalah prinsip kegiatan ekstrakurikuler yang didasarkan pada minat, potensi, dan bakat masing-masing siswa

d. Etika profesi yang menjadi prinsip dalam kegiatan ekstrakurikuler meningkatkan motivasi siswa untuk bekerja dengan bagus, baik dan berhasil

e. Menarik Kesenangan ; inilah prinsip kegiatan ekstrakurikuler dalam suasana yang disanyangi, disukai, dan dicintai siswa

f. Kepentingan Sosial : merupakan prinsip dari kegiatan ekstrakurikuler yang dilaksanakan untuk kemaslahatan masyarakat

Kegiatan ekstrakurikuler dapat membantu meningkatkan prestasi akademik. Kegiatan ekstrakurikuler tidak memasukkan tema yang terpisah dari topik lain, tema dapat disampaikan bersamaan dengan kegiatan ekstrakurikuler, karena kegiatan tersebut merupakan bagian penting dari kurikulum sekolah, kegiatan ekstrakurikuler dapat dijadikan wadah bagi siswa untuk menyesuaikan dengan bakat dan minatnya. Menurut Karim melalui kegiatan tersebut. Siswa dibimbing untuk memiliki kepribadian yang universal dan abadi contoh ujur, kasih sayang, disiplin, menghargai kemajemukan, semua aspek tersebut akan menunjang keberhasilan siswa di masa depan ${ }^{10}$

Berdasarkan penjelasan teori yang ada dapat disimpulkan bahwa kegiatan ekstrakurikuler, siswa dapat meningkatkan pemahaman mereka. Tentang topik yang berkaitan erat dengan pengajaran dikelas. Melalui kegitan tersebut siswa juga dapat mengembangkan bakat, minat, dan pontesinya, Indikator Kegiatan Ekstrakurikuler terhadap prestasi akademik

\footnotetext{
${ }^{8}$ Daryanto, Administrasi dan Manajemen Sekolah (Jakarta: Reneka Cipta,2013) 146

${ }^{9}$ Ibid., 288.

${ }^{10}$ Karim, Pengaruh Keikutsertaan Siswa dalam Bimbingan Belajar dan Ekstrakurikuler terhadap Prestasi Belaja Matematika, JPM Matematika, JPM IAIN, Antasari Vol 1 No, 1 (2013), 58.
} 
yaitu partisipasi aktif, individu, pilihan, etika profesi,dan kesejahteraan masyarakat. Dengan Kegiatan tersebut disekolah khususnya SMADA Lamongan diharapkan Standar Kompetensi Lulusan juga dapat meningkat.

\section{Fungsi Kegiatan Ekstrakurikuler}

Dalam Pedoman Pengembangan diri Menteri Pendidikan Nasional tentang Standar Isi Pendidikan untuk sekolah menengah dan sekolah dasar, tahun 2006, fungsi kegiatan ekstrakurikuler dijelaskan sebagai berikut :

a. Sosial yaitu fungsi kegiatan ekstrakurikuler untuk mengembangkan kemampuan dan rasa tanggung jawab siswa.

b. Rekreatifi merupakan fungsi dari kegiatan ekstrakurikuler untuk menciptakan suasana yang rileks. Menyenangkan peserta didik yang mendukung proses perkembanganny, persiapan karir adalah peran kegiatan ekstrakurikuler untuk mempersiapkan peserta didik dalam mengembangkan karirnya,

c. Pengembangan adalah fungsi kegiatan ekstrakurikuler sesuai dengan bakat, potensi dan minat siswa untuk mengembangkan kemampuan dan kreativitasnya.

\section{Keterlibatan Siswa dalam Ekstrakurikuler terhadap Standar Kompetensi Lulusan}

Berdasarkan Kementrian Pendidikan Nasional dan Kebudayaan Republik Indonesia, kegiatan siswa sekolah khususnya ekstrakurukuler. Merupakan kegiatan yang terkoordinasi dan terintegrasi dengan kegiatan sekolah lainnya, untuk mendukung terwujudnya tujuan kurikulum,kegiatan tersebut dikoordinasi disini. Merupakan kegitan yang dilakukan sesuai dengan program yang ditentukan, dalam proses melakukannya kegiatan ekstrakurikuler dibimbing langsung oleh guru. Sehingga waktu pelaksanaanya sangat lama, menurut Amal A.A kegiatan ekstrakurikuler di sekolah membantu meningkatkan kecerdasan, kegitan ini merupakan bagian penting dari kurikulum sekolah, maka bukan merupakan suatu tema yang terpisah dari topik lain dan dapat dilaksanakan sambil menyampaikan tema ${ }^{11}$

Dari uraian diatas bisa ditarik suatu kesimpulan bahwa partisipasi siswa dalam kegitan ekstrakurikuler berkaitan dengan pencapaian Standar Kompetensi Lulusan sekolah melalui kegiatan ekstrakurikuler, siswa bisa memperoleh wawasan tentang mata pelajaran yang berkaitan erat dengan pelajaran di kelas, biasanya yang menginstruksikan siswa untuk mengikuti kegiatan ekstrakurikuler adalah seorang guru dibidangnya masing-masing. Melalui kegiatan tersebut anda bisa menyebarkan, minat, bakat, potensi yang dipunyai. Salah satu kegiatan tersebut adalah keberagaman, hampir semua bakat, minat anak muda bisa dijadikan bagian dari kegitan ekstrakurikuler.

\section{Penutup}

Kegiatan ekstrakurikuler mengacu pada kegiatan yang berada diluar jam sekolah normal. Yang bertujuan untuk memperluas pengetahuan, serta membimbing minat dan bakat siswa. Kegiatan ekstrakurikuler dapat membantu siswa memperluas bidang pengetahuannya. Menjadikan prestasi belajar siswa menjadi yang terbaik. Dari segi kognisi, emosi dan psikomotor, kegiatan ekstrakurikuler berdampak pada peningkatan efek belajar siswa. Kegiatan tersebut dapat menarik bakat dan minat siswa. Dan melibatkan siswa dalam pembelajaran sebelum masuk ke kelas. Namun kegiatan tersebut merupakan bagian dari proses pembelajaran. Oleh karena itu perlu diadakan kegiatan ekstrakurikuler untuk meningkatkan Standar Kompetensi Lulusan yang meliputi 3 aspek : pengetahuan, sikap , keterampilan, siswa tidak dapat menerapkan pengetahuan yang mereka peroleh dikelas, untuk kehidupan sehari-hari. Misal siswa hanya memahami makna akhlaq saja. Tetapi sikap dan

\footnotetext{
11 A.A AMAL Mengembangkan Kreativitas Anak, (Jakarta: Pustaka Al-Kautsar, 2005), 378.
} 
prilakunya masih jauh dianggap akhlaq yang bagus dan baik, oleh karena itu kegiatan ekstrakulikuler hadir untuk membantu siswa dalam melaksanakan kegiatan didalam kelas berupa pelajaran di kelas. Agar lebih membantu memahami dan mengaplikasikan ilmu yang diperoleh siswa dalam kehidupan setiap hari, serta bisa berperan, siswa juga dibiasakan memeiliki kepribadian yang didasarkan pada keutamaan yang mereka pelajari di kelas.

Sesuai Peraturan Menteri Pendidikan Nasional dan Kebudayaan Republik Indonesia tahun 2016 Nomor 20 tentang Standar Kompetensi Lulusan yaitu: Dimensi Pengetahuan : siswa mempunyai fakta, konsep, proses dan pengetahuan metakognitif pada tingkat spesifik, teknis, rinci, sains, kompleks, humaniora, budaya, seni, serta dapat memperluas pengetahuan diatas dengan diri mereka sendiri, masyarakat, negara, rumah, komunitas, sekolah dan lingkungan alam, kawasan ienternasional. Dimensi sikap : dimana peserta didik mempunyai perilaku yang mencerminkan sikap, sesuai dengan pertumbuhan anak dalam keluarga, masyarakat, sekolah, lingkungan alam, kebansaan dan negara, mereka percaya diri, jujur, tanggung jawab,mempunyai kepedulian,berkarakter, dan Taqwa kepada Tuhan yang maha Esa. Dan mempunyai kebenaran seuumur hidup dari peserta didik, kesehatan fisik dan mental, serta Dimensi Keterampilan peserta didik mempunyai kemampuan bertindak, kreatif, produktif, mandiri, kritis , berpikir, berkomunikatif melalui metode ilmiah untuk mengembangkan pembelajaran mandiri di bidang pendidikan.

\section{Daftar Rujukan}

Andry Novan wiyani. Menumbuhkan Pendidikan Karakter di SD Konsep, Praktek, dan Strategi. Jogjakarta: Ar-ruzz media ,2013,

AA, Amal. Mengembangkan Kreatiitas Anak Jakarta: Pustaka Al-Kautsar 2005.

Badan Standar Nasional Pendidikan. Peraturan Menteri Pendidikan Nasional tentang Ujian Sekolah/Madrasah dan Standar Kompetensi Kelulusan. Jakarta: Departemen Pendidikan Nasional. 2006.

Bambang, Syamsudar. Dampak Kegiatan Ekstrakurikuler Olahraga frekuensi Tinggi rendah dan kegiatan Ekstrakurikuler Bukan Olahraga terhadap hasil Belajar Siswa SMP Santa Maria Bandung. Dalam Jurnal Pendidikan Universitas Pendidikan Indonesia 2012.

Daryanto, Administrasi dan Manajemen Sekolah. Jakarta: Rineka Cipta. 2013.

Hidayah, Sakdiah Renaning. Pengaruh Kegiatan EkstraKurikuler (Tartil Qur'an) Terhadap Prestasi Belajar PAI Siswa Di Kelas Xi SMA $N 1$ Lawang. Skripsi. UIN Malang. 2009.

Karim. Pengaruh keikutsertaan siswa dalam bimbingan belajar dan ekstrakurikuler terhadap prestasi belajar Matematika. JMP Matematika. JPM IAIN AntasarifVol. 1 No. 1. pp 1-8. 2013.

Moeleong, Lexi J. Metodologi Penelitian Kualitatif. Bandung: Remaja Rosdakarya. 2002.

Saputra, Yudha M. Pengembangan Kegiatan KoEkstrakurikuler. Jakarta: Depdikbud. 1998.

Suryabrata. Psikologi Pendidikan. Jakarta: PT Rajagrafindo Persada. 2011.

Suryosubroto, B. Proses Belajar Mengajar di Sekolah. Jakarta: Rineka Cipta. 2002.

Permendikbut no 62 tentang Ekstrakurikulers. tahun 2014

Wiyani, Novan Ardy. Menumbuhkan Pendidikan Karakter di SD (Konsep, Praktek dan Strategi) Jogjakarta : Ar-Ruzz Media. 2013.

Yanti, Noor. Rabiatul Adawiah, Harpani Matnuh. Pelaksanaan Kegiatan Ekstrakurikuler Dalam Rangka Pengembangan Nilai-Nilai Karakter Siswa Untuk Menjadi Warga Negara Yang Baik Di Sma Korpri Banjarmasin. Jurnal Pendidikan Kewarganegaraan: Volume 6, Nomor 11. 2016. 